\section{Side-effects to the use of laptop computers: erythema ab igne}

\author{
Lisa Linnea Soholm Secher, \\ Dina Vind-Kezunovic, \\ Claus Otto Carl Zachariae \\ Department of Dermatology, Copenhagen \\ University Hospital Gentofte, Denmark
}

\section{Abstract}

The use of laptop computers is increasing, and many children and young adults spend hours with their laptops on their laps daily. We report a case with erythema ab igne on the thigh of a 17-year-old girl, induced by use of laptop computers four to five hours daily for nine months.

\section{Case Report}

The use of laptop computers has become popular over the last ten years. Computer technology is refined continuously and the need for immediate access to information from the Internet increases.

A 17-year-old girl with no past medical history presented with symptoms of burning and itching experienced on the front of the left thigh for nine months. On physical examination, there was a brown, reticular, nonblanchable cutis marmorata on the left anterior thigh, approximately the size of a palm (Figure 1). Blood tests including ANA screening were normal. A skin biopsy showed minimal dermal inflammation. The patient had not been exposed to heat sources, such as radiators, stoves, or hot-water bottles. On further questioning, it was found that three months before the symptoms appeared our patient purchased a laptop, which she used four to five hours daily. When asked directly, our patient remembered that the discomfort of the area often appeared when using the laptop. The laptop's battery was localized at the left side of the computer, which corresponded with the localization of the rash. The diagnosis was erythema ab igne causae laptop.

The temperature on the thighs was measured after our patient had been sitting with the laptop on her thighs for an hour (Figure 2). The temperature started at $27^{\circ} \mathrm{C}$ on both

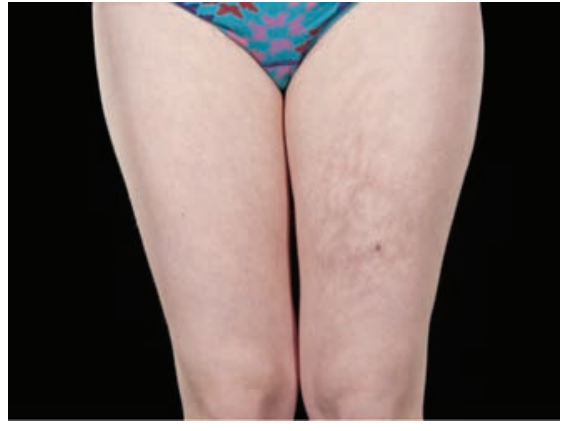

Figure 1. Erythema ab igne on the left thigh.

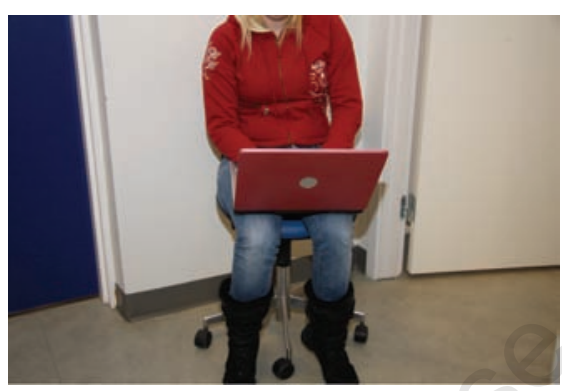

Figure 2. Our patient in her usual working position with the laptop, while thigh temperature was being measured.

thighs, and after an hour the temperature of the left and right thighs was $38^{\circ} \mathrm{C}$ and $33^{\circ} \mathrm{C}$, respectively.

\section{Discussion}

Erythema ab igne ("redness from fire") is seen rarely in young patients. The condition is seen usually in elderly people exposed to heating from repeated applications of heating pads or hot-water bottles. Erythema ab igne also occurs in cooks and bakers exposed to stoves, ${ }^{1}$ and historically it was seen in workers shoveling hot coals. The continuous exposure to infrared radiation initially causes transient erythema, progressing to reticulate pigmentation and keratosis. These lesions can develop later into squamous cell carcinomas. ${ }^{2}$

Because erythema ab igne is a precancerosis in line with actinic keratoses, ${ }^{3}$ it is important to recognize this new cause of erythema $a b$ igne, especially as we must expect to see it more in children in the coming years. If the heat exposure is stopped early, the prognosis is
Correspondence: Lisa L.S. Secher, Callisensve 12, 2.tv, DK-2900 Hellerup, Denmark.

E-mail: lisa.secher@webspeed.dk

Key words: laptop, erythema, side-effect, reticulate pigmentation.

Contributions: LLSS main idea, primary manuscript written in Danish; DV-K translation to English, proofreading; COCZ writing the main manuscript, proofreading.

Conflict of interest: the authors report no conflicts of interest.

Received for publication: 8 July 2010 .

Accepted for publication: 8 July 2010.

This work is licensed under a Creative Commons Attribution 3.0 License (by-nc 3.0).

(C) Copyright L.L.S. Secher et al., 2010

Licensee PAGEPress, Italy

Dermatology Reports 2010; 2:e11

doi:10.4081/dr.2010.e11

extremely good. Erythema ab igne may not be the only side-effect to the use of laptops on the thighs. Some studies suggest that the use can influence male fertility. When laptops are placed on the anterior aspects of the thighs, the scrotal temperature rises approximately three degrees after an hour, which perturbs spermatogenesis, and hence can influence male fertility.

Although the name laptop invites using the computers directly on the lap, we believe it is necessary to warn about the possible sideeffects, as it may cause chronic damage to the skin. Use of a protective blanket or plate is advisable.

\section{References}

1. Bachmeyer C, Benaid P, Bégon E. Laptop computer as a modern cause of erythema ab igne. J Eur Acad Dermatol Venereol 2009;23:736-7.

2. Jagtman BA. Erythema ab igne due to laptop computer. Contact Dermatitits 2004; 50:105.

3. Bilic M, Adams BB. Erythema ab igne induced by a laptop computer. J Am Acad Dermatol 2004;50:973-4.

4. Sheynkin Y, Jung M, Yoo P, et al. Increase in scrotal temperature in laptop computer users. Hum Reprod 2005;20:452-5. 